\title{
The late modernist community in the late socialistic block of flats: the issue of urban neighbourhood vitality in Poland
}

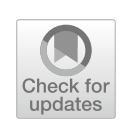

\author{
Marek Nowak $^{1}$ (D) Andrzej Siatkowski²
}

Received: 6 May 2020 / Accepted: 19 April 2021 / Published online: 11 May 2021

(c) The Author(s) 2021

\begin{abstract}
The question of the big-city neighbourhood seems important due to the discussion on the condition of modern cities. The issue is centred on the problems of sustainable development and designing social relations. The problem of the neighbourhood in relation to various forms of residence triggers a discussion rooted in the classic issues of sociology as a discipline. In the proposed article, the researchers address the problem of the late socialistic block of flats, attempting to diagnose the condition of the modern urban community in the developmental context of Central Europe, based on the neoclassic concept of 'spatially determined social circle'. The text introduces the issues of 'socialist modernism' using the available Central European literature. In the research part, the data obtained from an online survey on the subject conducted in 2019 in three Polish cities and from a nationwide online survey on the same subject are statistically analysed. The linear regression analysis suggested the relative vitality of the block form of residence, whose sources are both economic and social. The problem of traditional forms of accommodation and urban neighbourhoods has become a hotly debated political issue that triggers a scientific reflection on the phenomena of integration and disintegration in cities. In this context, the issue of the vitality of the forms of housing seems important not only for diagnosis purposes but also for predictions for the forthcoming decades. The case to be analysed herein is that of the late socialistic block of flats (LSBF) in Central and Eastern European countries, which for some is an anachronistic form of residence whereas for others is a partial solution to the insufficient market dynamics intended to meet people's housing needs. In this context, we ask four questions based on a hypothesis regarding LSBF urban neighbourhood vitality in Poland. The first question is a partly theoretical question based on the conceptualisation of social circles: To what extent does living in an LSBF modify one's sense of belonging to a social circle? The second question concerns the empirical findings regarding the LSBF neighbourhood: What is the neighbourhood assessment related to declared residence in an LSBF? The third question concerns more specific subjects related to the LSBF neighbourhood: To what extent does living in an LSBF affect the declared depth of neighbourly relations? The fourth and last question relates to the notion of vitality of the LSBF neighbourhood: Does the length of residence in an LSBF impact the interactions between the neighbours therein? The questions concerning the present-day LSBF cannot be answered without historical references to the concept of the city of socialist modernism. It is only
\end{abstract}

Extended author information available on the last page of the article 
from the genetic perspective dating back to several decades that we can understand the dynamics of the process, which has been marked by a few fundamental tribulations.

\section{Theoretical and historical introduction}

The neighbourhood, as a social phenomenon, remains one of the most classic research subjects in the field of urban sociology and in sociology in general. Paradoxically, it was connected with the phenomenon of spatial mobility rather than with permanent residence in the 19th and early twentieth centuries. Let us not forget that it was industrialisation that spurred the construction of city centres with concentrated populations. The neighbourhood issues were of paramount importance in such context as they denoted the mechanism of shaping a modern mass urban society in which, as a result of the breaking of the traditional social bonds, clusters of ethnically and classically diverse communities collided under new conditions, signalling the beginning of a metropolitan form. The conduct of studies devoted to the neighbourhood, associated with the so-called Chicago School, perfectly illustrates this direction of scientific reflection driven by social tension and social problems, and its evolution over the next few decades. As Ben Merriman stated, 'Notable lines of research examine residential segregation, access to employment, violence, disease, health, and perceptions of local disorder using a variety of measures' (2015). ${ }^{1}$ A good illustration of the classic approach to the neighbourhood problem may be the article by McKenzie (1922), which analyses the spatial dimension of neighbourhood relations in reference to religious groups (a typical perspective of cultural diversity in such periods), in Columbus, Ohio.

Nowadays, the issues of neighbourhood research, which refers to the Chicago School sociology based on a shared interest in neighbourly relations connected with minorities issues, more often indicate the consequences of 'taming' and rooting out the heterogeneous, multicultural and secularised urban society. We associate this modern society with the concepts of 'community attachment' and 'place attachment' linking an entity to a group or place (Hidalgo \& Hernandez, 2001; Kasarda \& Janowitz, 1974). Here, we find the conditions of modern capitalism of services and knowledge (Castells \& Cardoso, 2005) rather than capitalism of mass labour and mass immigration dating back to the beginning of the twentieth century. Due to the cultural contextualisation and the humanistic coefficient perspective (Znaniecki's concept: Thomas \& Znaniecki, 1958; Hałas, 2007: 148), it is worthwhile to analyse the consequences of an urbanisation variant that we know from East-Central Europe (Musil, 1993, 2005; Enyedi, 1996; Stanilov, 2007a, b; L'Heureux, 2015; Drozd, 2017; Jász, 2018) as a specific phenomenon, where separate analytical contexts (presented in the conceptualisation part of this paper) were developed under the influence of some sort of isolation. The notion of 'isolation' is understood here simply as a consequence of the existence of the so-called Iron Curtain; but now, almost half a century later, it can also be seen as a culturally embedded phenomenon (Woźniak, 2014). The key process for EastCentral Europe was as follows: a shift to a 'real socialist city' (1949-1989); then, after 40 years, through a deep economic and investment crisis, another shift to a post-socialist city in the 1990s (Hirt, Ferenčuhová, \& Tuvikene, 2017); and finally, to a neoliberal city (Barczykowska, 2009; Kovacs \& Herfert, 2012; Hirt, 2013; Kabisch \& Grossmann, 2013;

\footnotetext{
1 It is worth mentioning that Merriman also suggests in his study that 'the strong conceptual similarities between the Chicago School and contemporary research suggest that revisiting this older body of work may be useful in clarifying the aims of contemporary urban research' (Merriman, 2015: 271).
} 
Szafrańska, 2013; Kotus, 2006; Węcławowicz, 2016). Jiři Musil described this phenomenon of urban evolution by titling a subsection of his text 'Urbanization strategies in Central and Eastern European socialist countries: From utopia to realism', which underlines the contralateral logic of the process (Musil, 2005: 30). This evolution had significant consequences for the logic of identity construction of urban communities (including the national one; Diener \& Hagen, 2013), but above all, it at least partly reconstructed the neighbourly relations. ${ }^{2}$ In addition, it should be noted that the phenomena of the so-called socialist city and post-socialist city (Hirt, Ferenčuhová, \& Tuvikene, 2017) do not concern only Central or Eastern Europe but are widespread. Worth mentioning here is the case of American cities, including the emblematic case of Brazil, but also of other cities built on the idea of egalitarianism, which undoubtedly had a favourable political context (e.g. in South Asia, Chandigarh). The case of Central Europe or Poland is specific in relation to the idea of a 'socialist city' as patterns were directly drawn from the Soviet model, which collapsed and disappeared but left distinct footprints. The global phenomenon may have been different although it started from similar ideological assumptions.

\section{Central and Eastern European socialist housing: the polish experience}

The Central European variant of the modern urban story includes, apart from the wellknown 'pre-revolutionary' urban formation in the second half of the nineteenth century (e.g. Łódź), "post-revolutionary social experiments related to the attempt to implement communist utopia after World War II. The Soviet regime underlined the social need to build a counterweight to the domination of cities, perceived as the carrier of bourgeois culture, like Nowa Huta near Kraków, but also smaller centres, such as Bełchatów, Głogów, Jastrzębie Zdrój, Konin, Legnica, Łęczna, Lubin, Płock, Polkowice, Puławy, Tarnobrzeg and Tychy. These in fact became 'new towns situated near the old ones' (Węcłowicz, 2016). These cities and towns were located both in the old and new industrial regions. The aforementioned phenomenon was associated with a sort of social handicap of still-rural central European societies (e.g. Poland, Hungary, Romania). It is here that large investment projects (i.e. the construction of a steel mill, a mine and a combined heat and power plant) were carried out with the aim not only of rebuilding the industrial infrastructure destroyed during World War II but also of changing the social structure and creating a new society characterised by the dominance of the working class culture (in opposition to the dominant rural society). When we describe the specificity of this form of urbanism, it is important to emphasise its de-marketisation and, as Gyorgy Enyedi says, the 'differences originated from the collective (mainly state) ownership of urban land and infrastructure, from the centrally planned allocation of development funds, and from the existence of comprehensive strategies for the development of the national settlement network in the socialist countries' (1996: 101). Moreover, 'it was the locational value of urban land that lay behind the territorial regularities in its usage; that is, its "rational" usage (minimisation of human efforts in terms of cost, travel time, etc., for performing the functions and/ or maximizing the output of the function)' (Enyedi, 1996: 104). Sonia Hirt pointed out that

\footnotetext{
${ }^{2}$ Starting by escaping from the countryside to the cities, through 'social coercion in housing choices' ('negative' choices), to finally considering housing a market choice (including the dynamics of privatisation processes; Lux, Kahrik, \& Sunega, 2012).
} 
'the ratio of public-to-private land and buildings (both in ownership and in use) was much higher than it was in capitalist cities. A significant difference also existed in the balance between the basic urban land uses, especially commercial and industrial ones' (Hirt, 2013: S32). As a result, socialist cities began to look slightly different with time. This does not mean, however, that we are presenting a different model of the urban development process; rather, 'East - Central European socialist countries replicated stages of a more generally applicable global process of urban development concerns with the ideas of modernism' (Enyedi, 1996: 102). ${ }^{3}$ To be fair, modernism did not immediately triumph in the 'socialist world'. In the so-called Stalinist period, from the 1930s to the 1950s, communist urbanism was dominated by neoclassicism and 'socialist realism', which was a step backward, to the architectural convention of the nineteenth century (Jász, 2018). It was the so-called thaw in the second half of the 1950s (after Khrushchev's speech in 1956) that created the basis for a change in perceiving mass construction, which is also described as a shift towards solving social problems (Jász, 2018: 4). The socialist modernism that emerged over time had a specific feature usually called 'socialist modernism', which refers to the specific variant of leftist modernism developed, for example, by Le Corbusier (Drozda, 2017: 116); it also had completely pragmatic premises. This is well illustrated by the status of prefabrication technology, which has become very popular in the so-called countries of people's democracy since the 1960s, having the largest share in the buildings completed in the 1970s or 1980s (Radziszewska-Zielina \& Gleń, 2014; Stanilov, 2007b). ${ }^{4}$ The bases of the popularity of socialist modernism were far-reaching standardisation, scale economies and reduced construction costs (the concept of 'houses factories' (Drozda, 2017) was adopted), assuming administrative control over the production process and the spatial planning policy for many years, which would be difficult to achieve under market conditions. Wassenberg described seven motives for building large housing estates (Wassenberg, 2018). It is worth mentioning that some economic and social factors underpin the attractiveness of modernism in the post-war period 'in the West'. These factors, however, were undermined over time; an increase in the standard of living and a reduction in the size of the working class in industry caused a decrease in the demand for low-quality mass residences, which are still desired 'in the East'. Apart from purely economic reasons, the motives for building large housing estates cited by Wassenberg also concerned hopes for a revised evolution of cities towards greater egalitarianism (Wassenberg, 2018: 42). It is worth pointing out the next four elements, also indicating the evolution of this form of residence. An important element of modernist thinking adapted in socialist modernism was the redefinition of the role of the street, which, as a result of the systemic restrictions (i.e. chronic shortage of goods and merchandises), also lost its service and socio-creative functions. Nevertheless,

\footnotetext{
3 Therefore, with the help of the solutions borrowed from the outside ideologically rooted in Athens Charter as the result of the fourth CIAM (International Congress of Modern Architecture) in 1933 (a document published in 1943; compare: Mumford, 2019) and the German School Bauhaus from the first half of the twentieth century (Szafrańska, 2013; Szafrańska, 2015: 46), efforts were made to create the foundations of a different, non-market (egalitarian) urban society. The document recommended the following: '23. Residential areas should occupy the best places in the city from the point of view of typography, climate, sunlight and availability of green space. 24. The selection of residential zones should be determined on grounds of health. 25. Reasonable densities should be imposed related both to the type of housing and to the conditions of the site. 26. A minimum number of hours of sunlight should be required for each dwelling unit...' (Charter of Athens, 1933, 2, https://portal.uur.cz/pdf/charter-of-athens-1933.pdf).

4 What we are referring to here are the times when, in general, the construction output was the largest even compared to the modern data. At the same time, in countries outside the Iron Curtain, the same technology lost its importance over time.
} 
even the maximum reduction in construction costs did not guarantee that in each case multiple services and the design of the social sphere followed the housing plans; most often this was not the case. ${ }^{5}$ As a result, there was still room to fill the existing deficits, a place to introduce new functions or innovative modifications, already in the most modern context.

It came to focus on the function of connecting functionally different areas, which promoted social atomisation rather than direct relations in the neighbourhood. Another aspect of this construction was the scarcity of meeting places that could make residents' gatherings possible, which was due to the deficiency of central public spaces in the convention of a market square. A hypothesis about the counter-agonist nature of this form of socio-modernist residences can be proposed. They were replaced by store complexes and recreational spaces (Musil, 1993). A contemporary remnant of this trend in shaping space is the deficit of public spaces in the vicinity of social modernist blocks of flats, which overlaps the construction proper to Le Corbusier; that is to say, the fact that the scale of buildings does not match the human scale. From a practical viewpoint, this meant (and means), for example, the limitation of social control mechanisms due to the wide distances that prevent facial recognition and eye contact (e.g. between the residents of the neighbouring buildings).

Another characteristic feature of this building type was the dominant greyness of concrete, testifying to the producers' minimalism (Hirt, 2013: S35). Another aspect of the space in question was, and sometimes still is, the colour phenomenon called 'pastelosis' (Nikolić, 2019), the tendency to repaint social modernist grey with light colours, testifying to the need to overcome the 'asceticism' of socialist modernism, which was fathomed shortly after the regime change. Moreover, repainting was often accompanied by thermal modernization (subsidized by public authorities), which significantly removed the weaknesses of socialist housing, making living in this infrastructure competitive from the point of view of operating costs, while maintaining the counter-agonistic nature of this type of construction.

\section{Social genius loci of the central and Eastern European city?}

The process of creating neighbourly communities 'from scratch', typical of the 1950s and 1960s, was most often a consequence of migration from city centres, villages and small towns to larger cities. It involved repeated variants of the tale of disintegration and reintegration that sociologists registered several decades earlier in Chicago (Thomas \& Znaniecki, 1958). The difference was that 'in the East', settlement was based on administrative decisions (not on the market) and on rational planning procedures, which were responsible for the overall vision of space. Through such procedures, the weaknesses of the chaotic urbanism of early capitalism were being removed by controlling at the same time the tendency of cities to spill over and 'become more rural'. Similar to their older and contemporary 'Western' colleagues, sociologists from Central and Eastern Europe monitored

\footnotetext{
${ }^{5}$ Nevertheless, the large-panel housing estates that emerged in the 1970s and 1980s already had the adequate social infrastructure (health centres, community centres) and educational infrastructure inscribed in the designed space. In some ways, after so many years, they have become not quite the intended form of implementation of the original socialist assumptions. Drozda describes it as follows: 'A characteristic feature of Polish Socialism was to introduce at some stage only two-height scales-five- and eleven-storey blocks of flats. This made it easier to obtain free space, but the disadvantage of such solution was often limited by the functional program, not including the recreational space (...). Usually, no green infrastructure was planned either' (Drozda, 2017: 117).
} 
the process of building/creating neighbourly relations in connection with the modern, wellknown form of implementation of Le Corbusier's utopia: mass, high-altitude, block residence (meeting the needs of the inhabitants; Rabaça, 2016). They did this, for instance, by putting appropriate spaces between blocks and providing educational and service amenities, which have become elements of the genius loci of a Central and Eastern European city. The motives for choosing the place of residence, in cases where this was at the discretion of individuals, did not differ from those modelled by residents who were not subject to 'central planning' (Enyedi, 1996). This resulted from the ineffectiveness of substituting market mechanisms with socialist planning (Staniszkis, 1992). Housing was therefore only partly statistically managed; on the other hand, the main factors that determined the dynamics of the settlement were the supply constraints and chronic shortages described in the once famous book Economics of Shortage by Janos Kornai (Kornai, 1980), which were then used by publicists to describe 'societies of shortage', characterising socialist societies in general. The ability to organise mutual support (neighbourhood solidarity) was a favourable and sometimes necessary condition for coping with the crisis, which was particularly intensified from the second half of the 1970s to the 1990s. At the same time, in ideological opposition to Soviet socialism, in the 'non-socialist world', based on a different (market) micro-logic, decision-making processes of dispersing and differentiating housing were going strong, along with the creation of areas combining the features of rural and urban settlements, which still effectively compete with city centre areas (Hesse \& Sidentop, 2018). The idea of living in a block of flats was (and is still) going through a crisis, as were the assumptions of modernism (Rowe, 2011). Symbolically, the beginning of the 1970s is considered the end of modernism 'in the West'; at the same time, 'house production' was gaining momentum in Poland, achieving the highest dynamics five years later. ${ }^{6}$

Thirty years after the fall of real socialism (1989-2019) and 100 years after the publication of Thomas and Znaniecki's opus magnum, the specificity of neighbourly relations in the spaces created by modern urban concepts of socialist construction remains an interesting training ground for the 'emergence' of an urban society. Unlike cities without communist experiences, post-socialist cities have so far not lost their position as the main place of residence in the cities (Stanilov, 2007a, b: 182), which is also the case in Poland. Neither are they subject to dynamic destruction, such as far-reaching relative depreciation, ghettoization, and slums (Bolt, 2018: 62), which justify, for instance, demolition or significant changes in form or function that occurred in the late 1970s in Western countries. One of the attempts to explain this phenomenon may be the overcrowding rate analysis that has been going on in the past 10 years. As indicated by the European Statistical Office (EUROSTAT) data, problems with the scarcity of residential spaces remain a part of the developmental specifics of Central European societies (see Fig. 1).

It is worth noting that there has been a noticeable systematic improvement of the living parameters (about $10 \%$ over 9 years), but it has not been sufficiently dynamic in countries such as Romania, Poland, Bulgaria and Hungary compared with their northwestern neighbours. It should also be added that the state of housing differs significantly in different countries in the region. This may include, among others, the condition of the LSBF segment in Poland, due for instance to the strong position of the so-called housing

\footnotetext{
${ }^{6}$ As Łukasz Drozda, author of an analysis of Polish housing, suggested, 'An interesting example is the Warsaw housing estate "Za Żelazną Bramą" completed in 1972. Its full opening took place parallelly to the demolition of the Pruitt - Igoe estate in the American St. Louis, considered to be the symbolic beginning of the global end of the reign of the modernist style' (Drozda, 2017: 116).
} 


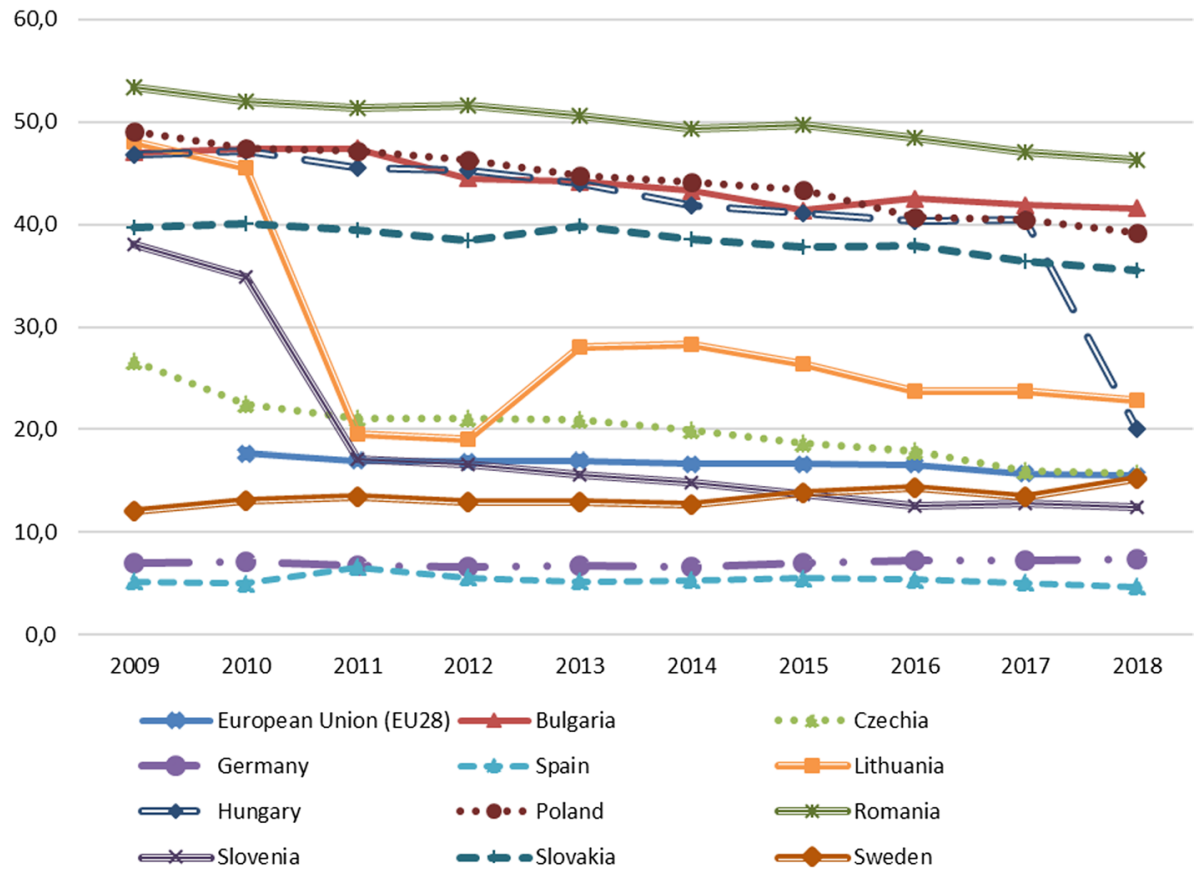

Fig. 1 Overcrowding rate by income quintile-total population. Source: Overcrowding rate by income quintile- total population-European Union Statistics on Income and Living Conditions survey. https:// appsso.eurostat.ec.europa.eu/nui/show.do?dataset=ilc_lvho05q\&lang=en

cooperatives in relation to state property, and the currently fragmented private property (Coudroy de Lille, 2015).

\section{The state of the art and operationalisation}

The problems of European post-socialist cities have drawn the attention of many researchers for many years in terms of social geography (Kubeš, 2013), although the studies on neighbourly relations in LSBFs have been limited, and descriptions of the Polish case are particularly rare. This is especially true for the literature in English on the subject. An interesting deviation from this rule is a study on neighbouring communities, focusing on the phenomenon of differentiating forms of residence under the influence of marketisation in Albania (Pojani \& Buka, 2015). It is worthwhile to pay attention to the extent to which such study's assumptions converge with those of the empirical material presented below (a quantitative analysis of the specifics of residence forms in post-socialist Tirana). Such assumptions concern (a) the intensity and frequency of interactions with the neighbours, (b) the relationships with the neighbours during the socialist era and (c) the perceptions of the physical quality and amenities of the neighbourhood and buildings (Pojani \& Buka, 2015: 70).

The aforementioned authors' main findings indicate correlations between the extent of relationships based on friendship, rootedness in the place of residence and positive neighbourhood assessments. This indicates that there is a correlation between the presence of 
neighbourly ties and the perception of the neighbourhood, with the arrangements for a lower level of young people's rootedness also being important. Another important empirical finding is the relative stability of the relationship that questions the image of a neighbourhood with weaker bonds, allegedly resulting from the growing spatial mobility. Based on the obtained data, the infrastructure, which is referred to in the article as LSBF and in the cited analysis as a 'socialist-' and 'post-socialist, mostly multi-family' infrastructure, maintains a positive relationship with having 'a number of friends among [one's] neighbours' (Pojani \& Buka, 2015: 73).

The cited study in some way continues the extensive tradition of research from the period of real socialism in Central and Eastern Europe. A similar tradition in Polish sociology contained studies worth mentioning that are not available in English. Since the 1960s, the category of neighbourhood and the research on it have been systematically included in the empirical urban sociology field, especially the research on housing life (cf. Ziółkowski, 1964; Turowski, 1973; Sosnowski \& Walkowiak, 1983; Szwaja, 1970), mainly in the new housing estates consisting of blocks of flats, which are supposed to implement the principle of 'a decent minimum for the maximum of the population' (cf. Ziółkowski, 1965: 53). What is important is what Smagacz-Poziemska called 'rural counterpoint' (SmagaczPoziemska, 2017: 141). This can be seen, for example, in the research on Nowa Huta (an industrial city built near the city of Kraków). Researchers were interested in the process of proletarianisation of peasants and in discovering the 'urbanisation of consciousness' of new district/city dwellers. Kryczka's research (1981) does not describe a simple erosion of ties but analyses 'a new quality in the field of social ties between dwellers' (Kryczka, 1981: 142). Even ceremonial or polite habits perform controlling functions while spatial interfaces provide an opportunity for observation (Smagacz-Poziemska, 2017).

New factors supported the academic discourse at the beginning of the new millennium. In the empirical research carried out in Łódź (2001: 2), Bujwicka noted a specific tendency to modify social relations as a consequence of the system's transformation process according to the heuristic perspective of the 1970s. 'New rules direct human activity towards seeking one's own benefits and allow one to treat ties in terms of investment' (Bujwicka, 2011: 103; Nowak et al., 2019). Kotus completes the contemporary perspective of neighbourhood/community relations, stating that social and spatial studies on the neighbourhood produce separate albeit interdependent analytical areas. The author does not use references to a network (which seems the next step in developing the concept of social circles) but writes about 'neighbourhood subsystems', understood as 'the area of direct neighbours, people or families living in adjacent flats or single-family houses, inhabitants of one staircase' (Kotus, 2007: 115; Nowak et al., 2019). This constitutes a next step leading to neighbourhood/community operationalisation offered by the study. We can also add that the suggested strategy for dealing with the problem close to the spatial-interactive perspective could be the expression of a tendency to embrace the micro-social perspective noticeable in the most recent Polish literature (cf. Bierwiaczonek, 2018; Majer, 2016; Nowak et al., 2019). Another subject can be the dynamics of local neighbourhood/community in relation to particular issues, such as a tendency to convert public green spaces into carparks (Smagacz-Poziemska et al., 2018).

Finally, going back to the main concept, we refer to the infrastructural and socio-spatial perspectives fitted into the existing field of social geography research (Clark, 2009). The first can be found behind the acronym RESTATE, ${ }^{7}$ where 'late-socialistic block-shape large

\footnotetext{
7 The concept of the RESTATE project assumed a framework around which the research concepts were formulated: "Very often, policy and practical responses have only required additional funding. But, after lengthy and costly experiences with different attempts to improve the conditions in the estates, it is now
} 
housing estates are spatially isolated groups of buildings consisting of over 2000 flats built in the second half of the twentieth century, planned and fully or partly financed by the state' (Szafrańska, 2013). The semantic field of this definition well reflects the specificity of the socialist form of residence that combines social architectural concepts, the realisation of social goals (framed ideologically) and higher standards regarding common areas: green areas, available living services, etc. The RESTATE project itself suggests the existence of a fundamental problem requiring social (public) intervention, bringing to mind the concept of the revitalisation of old city centres. It seems that the attractiveness of this type of residence has not fully declined in Central Europe (Kotus, 2006; Barczykowska, 2009; Kovács \& Herfert, 2012; Kabisch \& Grossmann, 2013; Kubeš, 2013; Szafrańska, 2015). As such, we can very carefully hypothesize that there will be a renaissance of social modernism in the Central and Eastern European countries (Springer, 2012a, b; Łukasik, 2014; Cymer, 2019). A similar direction of interpretation albeit not as far-reaching in relation to Central Europe, including Bucharest in particular (Marin \& Chelcea, 2018), was brought forth by a 2018 publication referring to the RESTATE project (Baldwin et al., 2018). The diagnosis of the condition of modernist blocks of flats treats cases of post-socialist construction (the former Eastern Bloc) as special cases of a more universal perspective on urban evolution in European cities. The authors see this form of housing as having a potential, largely social. The same authors are aware of the great differences in the location of this form of construction on a specific stratum of forms of housing, which shifted from the formula of 'the right to housing for all' to becoming a commodity subject to market speculation (Tsenkowa, 2009). Another specific context is public policy and projects of mass privatisation of apartments under preferential conditions, which allowed for the rapid creation of a social segment: the middle class. On the other hand, however, it has initiated gentrification or even filtration processes wherever the reasons for location attractiveness were justified (Tsenkowa, 2009: 135, 139). Here, it seems that Central European examples stand out the most, although not without exceptions.

The above conceptualisation resulted from the belief that the specificity of construction (e.g. its attractiveness) does not directly refer to neighbourly relations, although it undoubtedly has an impact on such. Here, the basis for a study on the late modernist community is the classical concept of a 'social circle', a concept with a long tradition introduced by George Simmel in an early 1920s publication. The essence of the conceptualisation can be related to the directness of social relations and individual motivations (including voluntary ones), which determine the content of these relations and therefore maintain them (Nowak et al., 2019). This concept, referring to the classic approach of Charles Kadushin (Alba \& Kadushin, 1976), was used, among others, to describe the dynamics of discourse culture production based on different levels of intensity of participation (Kadushin, 1976).

Using a perspective detached from the acting subject, the neighbourhood circle illustrates the concentricity of social relations. ${ }^{8}$ In the interpretations of sociologists it appears to be in the context of the concept of the intersection when we move from interpreting

\footnotetext{
Footnote 7 (continued)

necessary to find out what really seems to work and how. Nowadays, it seems most important to integrate policies across departments and between different organizations. Local communities, private partners and different parts of the governmental organization cooperate in partnerships. When learning about these complex organizations the different social and economic contexts will be taken into consideration' (http://resta te.geo.uu.nl/results/).

8 The concept of concentricity, this time in relation to space, is also used by the ecological current of the Chicago School (Merriman, 2015: 272).
} 
group relations, such as in relation to the primary group, towards interpreting the interactions of many groups with fuzzy membership boundaries, up to the concept of network relationships focusing on the circulation of information, the positions of the network nodes and their distribution (much more frequently used nowadays; Pescosolido \& Rubin, 2000). Regarding the classic Chicago School earlier mentioned, it refers to the concepts of 'community attachment', 'ecological space' and 'subjective space', bringing up the idea of housing spatial zoning and also the issue of subjective perception of space, which evolves over time (Kasarda \& Janowitz, 1974; Merriman, 2015: 271). As McKenzie states, creating a starting point for contemporary analyses, 'It is obvious that the term $<<$ neighbourhood $>>$ in these expressions is used in the restricted sense as implying, for the most part, the street on which the family resides, or at most not more than the immediately adjacent streets. And the $<<$ neighbours $>>$ are the people living on the same street with perhaps the families on the street in the rear whose back doors are adjacent' (1922: 610).

The proposed paraphrase of the concept assumes the possibility of belonging to very different social groups/social circles connected only by the space in question. Interestingly, the intersection of group affiliation contained in Simmel's classic concept also provides a basis for interpreting the depth of neighbourly relations in terms of an abstract continuum, but also in terms of a historical modernisation process.

The aforementioned intersection may first mean crossing family-related direct relations (this can refer to relationships within small agrarian communities and to the classic position of Thomas and Znaniecki or the already mentioned point of view of McKenzie). This process can be observed through mediated relationships and the individual's participation in many such structures (groups: peers or professionals in social circles constructed in the context of the block, housing estate, city), up to the relationships created on the basis of shared values and norms, which we are able to identify as being present in our block, housing estate, district or city through social media discussions, for instance.

Referring to the foregoing considerations, the concept of a space-bound social circle is based only on the fact that people stay together in a spatially delimited and determined area. On the other hand, the neighbourhood is formally considered a specificity of the spatially determined social circle, which is mainly determined by the creation of norms and the implementation of social control mechanisms (Nowak et al., 2019). It is worthwhile pointing to another feature of the circle observed by Kadushin ${ }^{9}$ : its perception is limited to individual perspectives, and its mechanisms (being part of it or being 'outside' it), including normative processes, clearly transcend such unitary scope. The process of establishing a neighbourhood circle is an interesting research topic, whose scope is created by the urban form of residence, exceeding the individual perception of the operating entity and being a collective-effort product par excellence. This enhancement can be described in research by answering questions about a sense of connection with a block of flats, a housing estate, a district or a city, indicating specific factors that on the one hand remain connected with the form of residence and on the other hand favour the aforementioned intersection of the

\footnotetext{
9 'Circles have some distinct properties, which often prove puzzling to observers and which shape circles as emergent, low-visibility, interstitial networks. First, circles have no clear boundaries, and the dividing line between the centre and the periphery is often arbitrarily drawn. Because the boundary lines are not especially clear and because any individual member of a circle can $<<$ see $>>$ only his immediate surrounding contacts, $<<$ natives $>>$ of circles frequently have only fuzzy, if not totally incorrect, notions of what their circle looks like' (Kadushin, 1976: 771).
} 
neighbourhood or the creation of new circles and factors that engender barriers during this process.

\section{Exploratory analysis of empirical data}

Within the framework of the empirical project, it was decided that a significant body of quantitative data would be created. Two types of quantitative research based on the sociological survey method were carried out. An online survey was used, and questionnairebased interviews were conducted. The online survey was conducted among Polish citizens aged 16 and over via Facebook. ${ }^{10}$ The survey asked about a few selected key issues: the problem of the declared relationship between a resident and a building or a housing estate, general assessment of one's neighbourhood, individual assessment of one's relations with one's neighbours and identification of the problems that most strongly affect the life of the neighbourhood. Questionnaire interviews were conducted among adult inhabitants of three selected Polish cities (Warsaw, Poznań and Wronki). Residents of Warsaw's Sady Żoliborskie and Saska Kępa housing estates and of Poznań's Batory and Armii Krajowej housing estates were selected for the study. As there are no housing estates in Wronki with characteristics similar to those of the housing estates in Warsaw and Poznań, the study was carried out in this locality on the basis of 10 starting points, including low blocks of flats, multiple-occupancy houses and single-family houses. Both the interview sites (specific housing estates) and the city were selected in such a way that different types of neighbourly relations could be compared with each other. ${ }^{11}$ The interview questionnaire was developed on the basis of questions from an online questionnaire, supplemented with additional questions. The tool that was used for the interviews was therefore developed on the basis of an already existing Internet tool (Fig. 2).

In the explanatory part, we first contrasted (A) the spatially centred neighbourhood circles, (B) the neighbourhood assessments, (C) the factors conducive to forging relationships, (D) problems with one's neighbours and (E) knowing one's neighbours in an LSBF and in other forms of residence (see Table 1).

The presented study data indicate a relatively lower sense of neighbourly relations between people living in LSBFs compared to people living in other forms of residence. What is worth mentioning is that the difference is relatively lower in relation to a wider spatially centred neighbourhood circle, such as a district or a city. The situation is similar when it comes to declared care for the building's surroundings and mutual assistance. In general, however, it is worth noting that the difference, although statistically significant, usually does not surpass $10 \%$, which means that one cannot talk about some form of model separateness or a sort of break from spatially centred neighbourhood circles in the case of the inhabitants of LSBFs. A similar conclusion applies only to the conditions of meeting one's neighbours (which confirms the hypothesis of 'counter-agonist' LSBF specificity).

\footnotetext{
${ }^{10}$ Initially, 3000 surveys were planned. In the course of implementation, it was decided that the assumed sample size would be reduced to 1500 surveys. Finally, 1860 completed questionnaires were collected, 1854 of which were included in the analysis.

11 Further analyses also used the results of questionnaire-based interviews conducted within the framework of field interviews held by the students of the Institute of Sociology of Adam Mickiewicz University in June-July 2019. As part of their internship, the students conducted a total of 233 interviews with residents of the estate.
} 


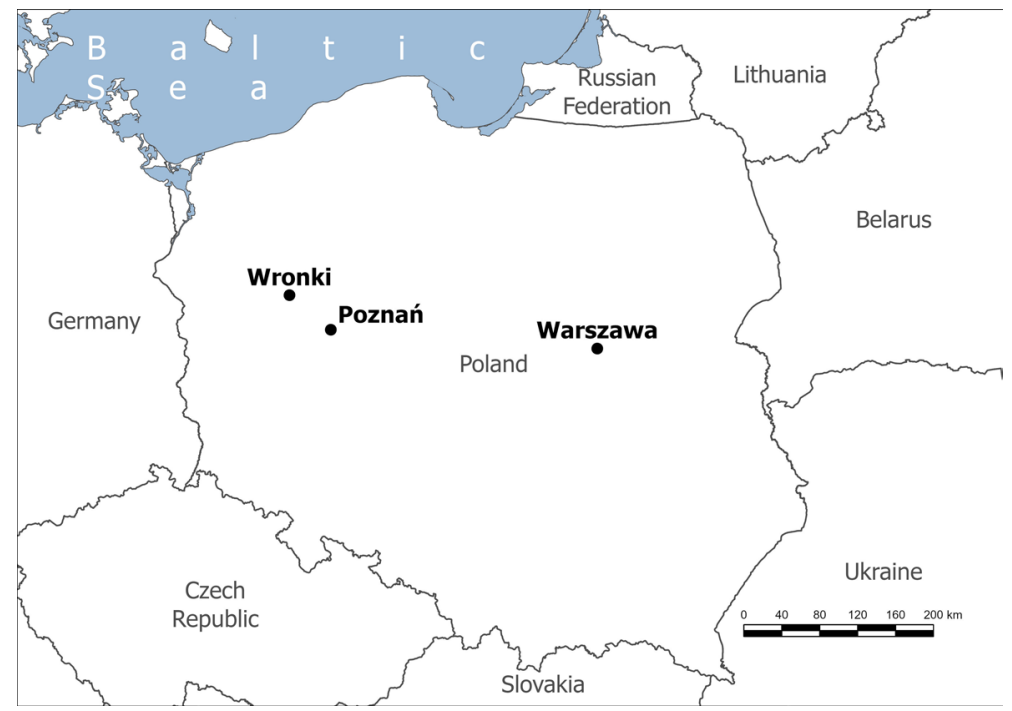

Fig. 2 Locations of cities where the questionnaire survey was conducted

The answers to the questions about the spatial infrastructure for meetings indicate a slightly higher emphasis on this last element of LSBF specifics. Similar to previous arrangements, the least disadvantageous aspect is the friendly space in the neighbourhood (e.g. playgrounds, green areas).

With no model differences, we can still find that LSFB has a higher level of phenomena that the respondents interpreted as a source of problems. Another issue is the knowledge of the neighbours and the construction and depth of relations within the neighbourhood. Clearly, purely instrumental forms of relationships based on customary greetings dominate in the context of relationships within other forms of residence. In the case of deeper relationships in LSFBs, they are distinguished by a significantly lower level of knowledge of neighbours as well as neighbourly intimacy. The relationships are thus definitely shallower, and as such, it can be assumed that the social control mechanisms are also weaker.

The aforementioned conclusions were confirmed to some extent by the linear regression analysis results. However, the results tell us something more about the significant mechanisms of constructing neighbourly circles in comparison with the cited Tirana studies (Table 2).

Among the variables that were taken into account, the size of the place of residence and the number of children in the household affect both indices and the indicator of the number of befriended neighbours in the same way. Generally, the people living in small cities (with less than 20,000 inhabitants) and in the rural areas show a higher sense of relationship and assess their neighbourhood better. Higher index values were also recorded for the people living together with children in the household. The lowest relative values of satisfaction with the neighbourhood and the lowest sense of connection with the city were observed among the inhabitants of the largest Polish cities (with over 500,000 inhabitants). With regard to the impact of the housing type, a relationship was found between living in an LSBF and neighbourhood assessment. The inhabitants of high blocks of flats assessed relatively worse than the other respondents the residents' care for their houses' surroundings, mutual neighbourly assistance and the possibilities for children to play outside or 


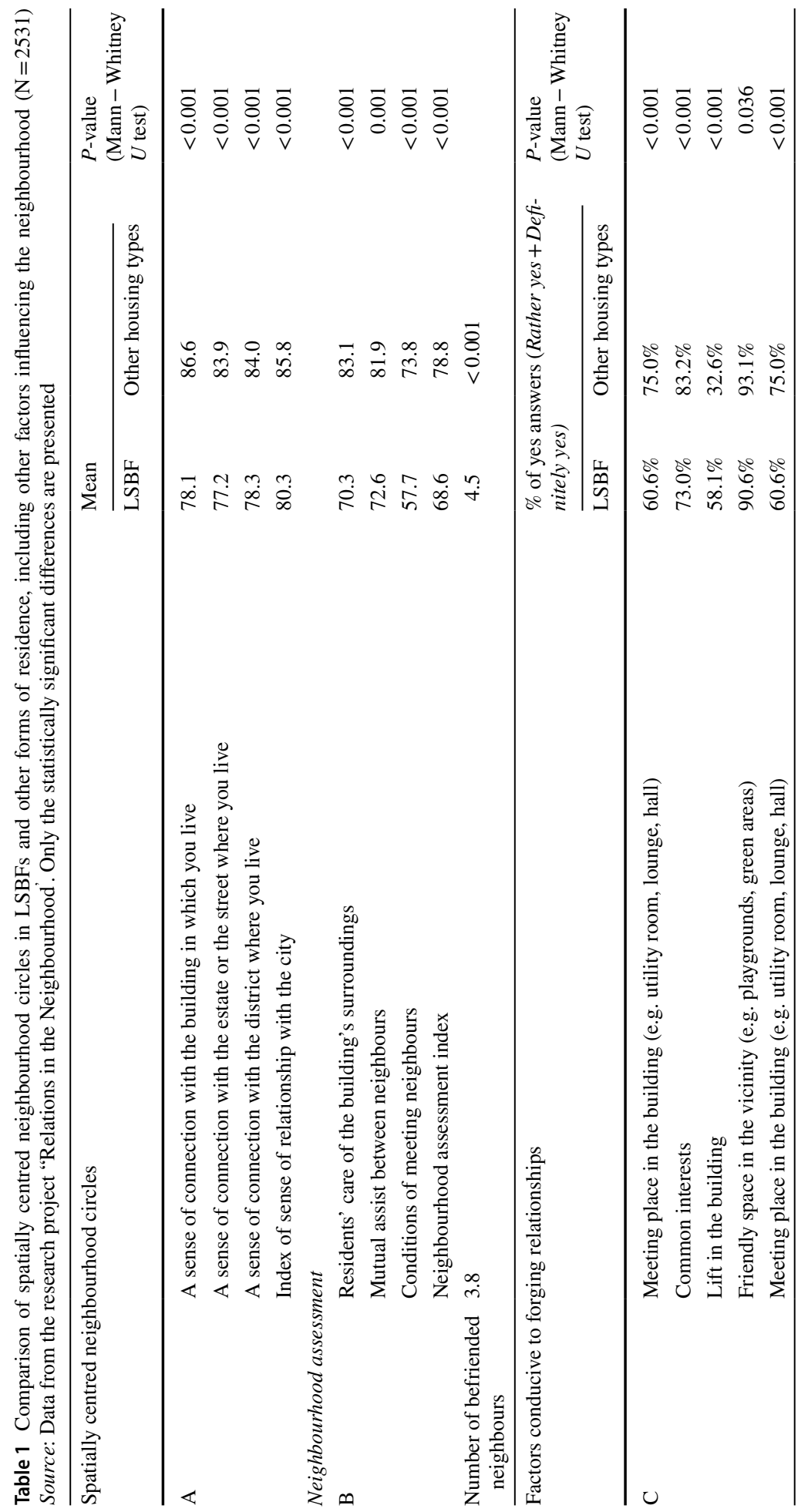




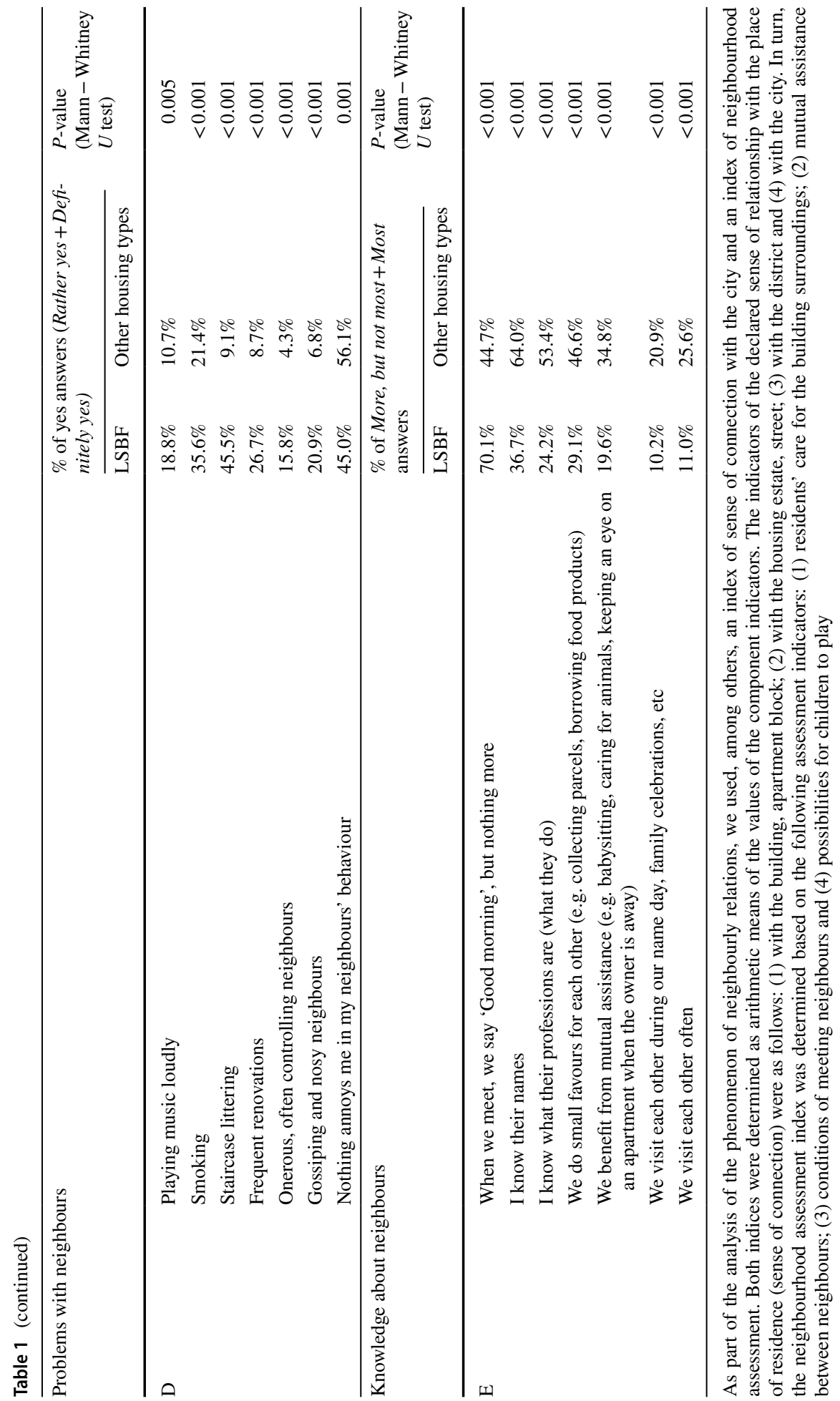




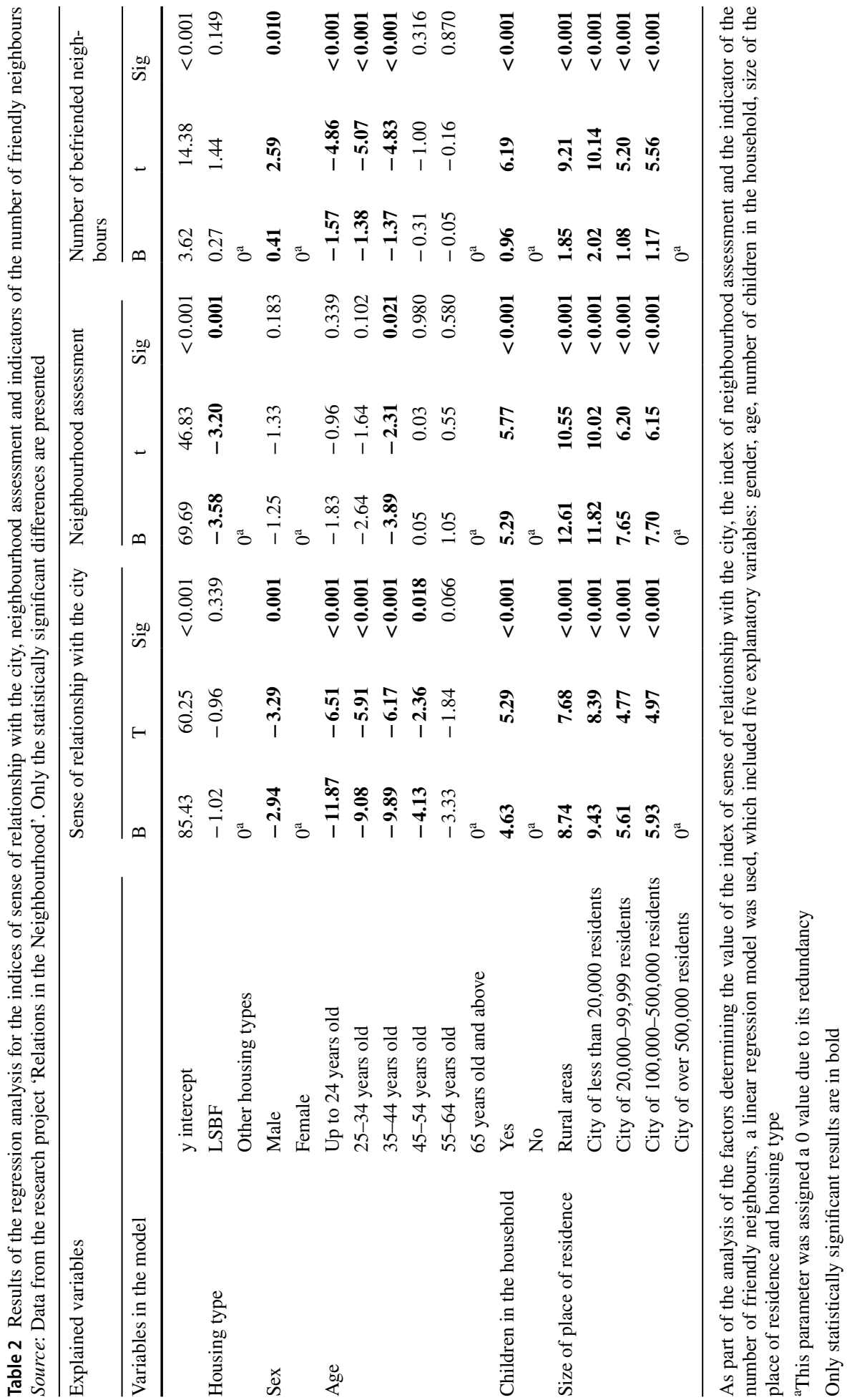


the conditions for neighbourhood meetings. In relation to the proposed indices, the LSFB residents did not differ significantly from the other residents but had lower neighbourhood ratings. It should be added that the blocks of flats' surroundings and recreational infrastructure are in fact usually currently in good condition due to the specificity of LSBF segment management in Poland, based on housing cooperatives or steering communities (consisting of flat owners). It turns out that the difference is not as big as might be expected. The reason for this positive evaluation may be the fact that there are different forms of financial support, including the support from EU funds. This applies especially to infrastructure aimed at the elderly or children. It can be assumed that an important element is the ability of housing cooperatives to finance greenery care (lawn mowing), also a result of the cooperative's economic situation, which has been stable for several years. At the same time, it can be assumed that the factors conducive to building neighbourly relations (e.g. having children) are similar in the LSFBs and the other housing types, which gives grounds for recommendations.

To answer the third research question, data from the LSBF housing estate located in Poznan were used. ${ }^{12}$ The conclusions from this part of the study are interesting because of the problem of the impact of the residence continuity on the vitality of neighbourly relations; it also indirectly indicates the dynamics of evolution of spatially centred neighbourhood circles (Table 3).

The survey results indicate a higher level of mutual benefits (small favours, mutual assistance) among the inhabitants who are more strongly rooted in the city and the housing estate (those who have been living in the city and in the housing estate for over 5 years). This can also be seen in the informative dimension of neighbourly relations: the people who have been living in the housing estate for a longer time know their neighbours better. This is perhaps one of the decisive answers to the questions about the relative vitality of living in the LSBF. On the other hand, it points to the importance of the traditional community factors binding residents, which in a way abstract from the existing market offer. There is a saying in Polish that goes, 'Old trees are not replanted.'

\section{Summary and discussion}

To summarise the report on LSBF, in the form of an idealising concept, it can be assumed that the real socialist specificity resulted not so much from the model separateness of the socialist city but from the imposition of a spatial (capitalist) policy of co-modification. It was substituted in Central Europe by the analytical and bureaucratic proceduralisation (under the condition of scarcity). The social context of residence also highlighted the loss of individualism of city dwellers, subordinated to the monumental functionality of multistorey buildings and the key role of the centralised state. Therefore, the housing form was adapted to the logic of the system, and in this sense can be considered rational. This affected the specificity of neighbourly communities, which were constructed 'top-down'. However, the communities quickly started processes of creating their own dynamics that

\footnotetext{
12 The analysis of the impact of the length of residence in the housing estate and in the city on the depth of neighbourly relations under the implemented project was carried out only on selected post-modern housing estates in the city of Poznan $(\mathrm{N}=281)$.
} 


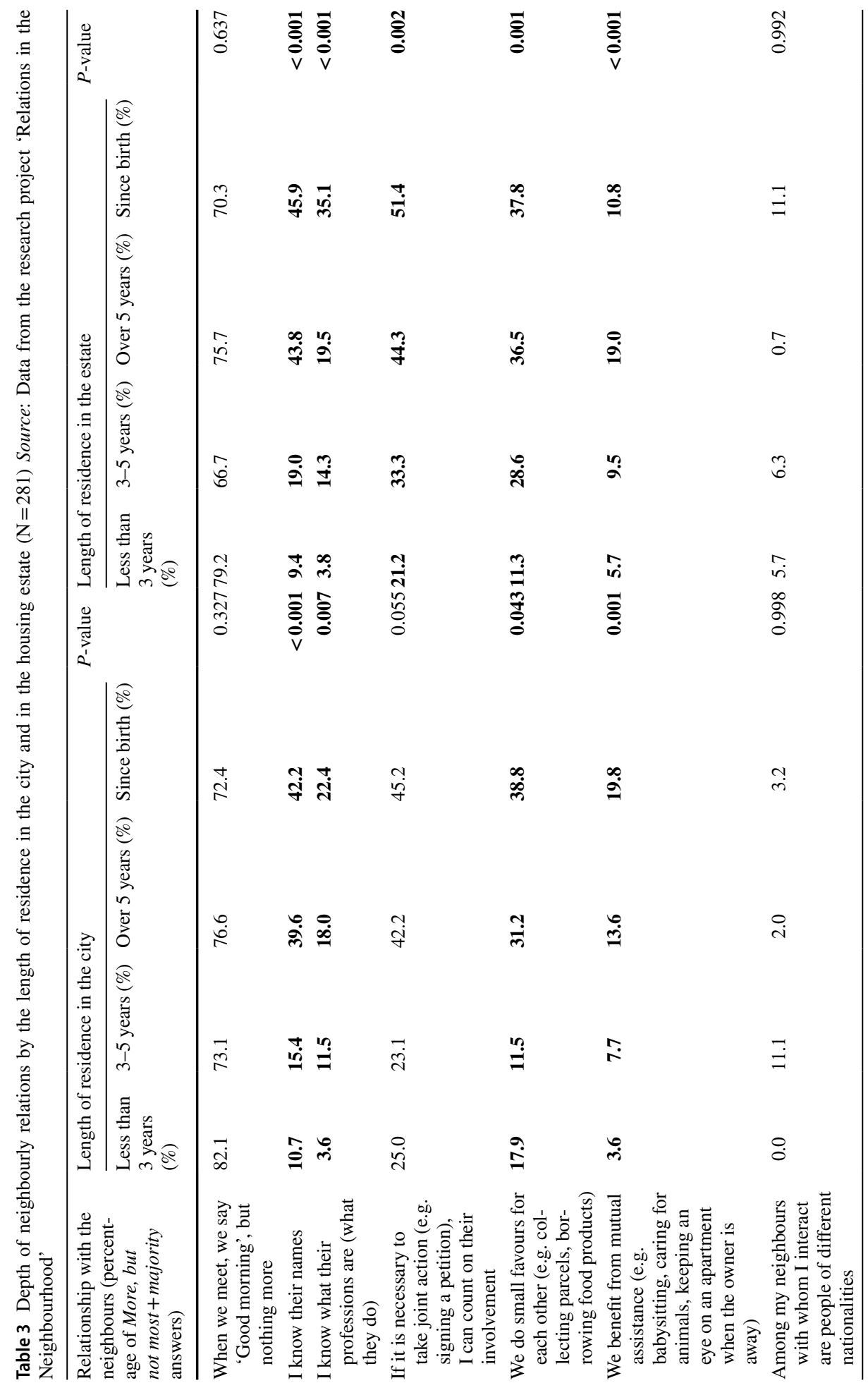




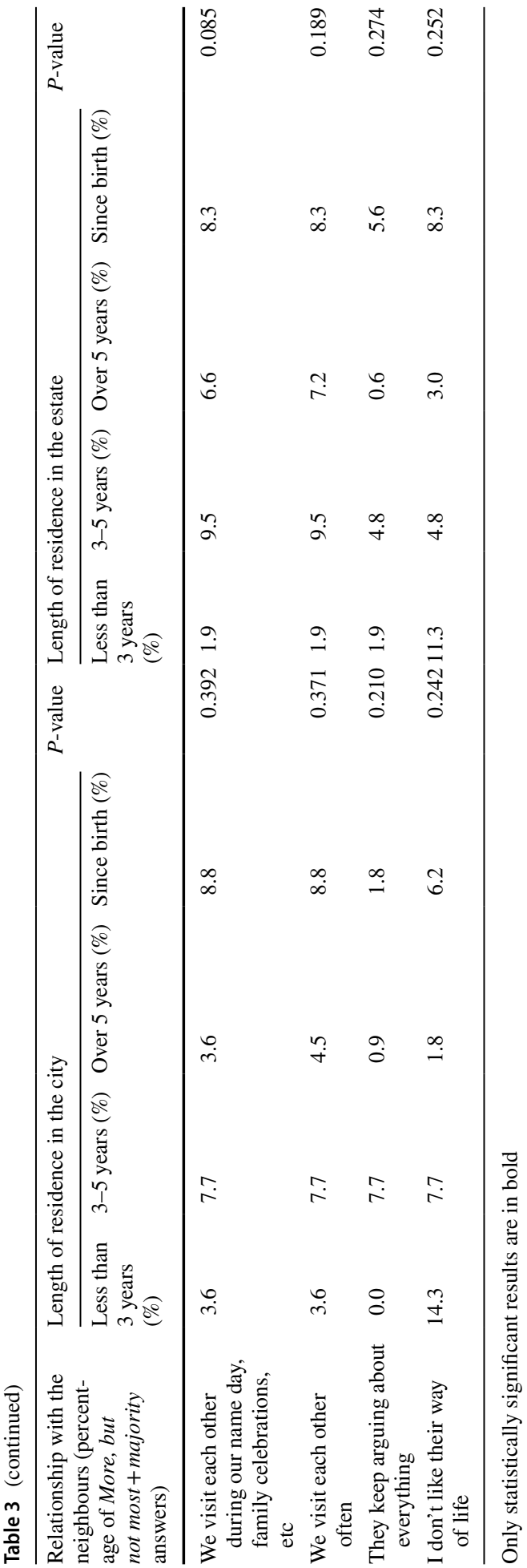


can be called dynamics of solidarity at the level of social interactions. ${ }^{13}$ Under the Central European conditions, it is a kind of 'afterlife' of modernism; its history turned out to be much more long-lasting than the one written on the basis of the Western European experience. Finally, as a result, as Hirt suggests, 'East - Central European cities are still different from their Western cousins' (Hirt, 2013: S36). This probably means two things: on the one hand, the persistence of a certain category of differences that we can call evolutionary or in transformation, and on the other hand, the emergence of new phenomena somewhat reminiscent of a recycling strategy, where the old and to some extent non-functional undergoes transformations while maintaining its attractiveness even in purely pragmatic ways.

The key to answering questions about the reasons for LSBF's vitality may be complex. The first factor concerns the consequences of the marketisation of housing resources and the change in the housing policy philosophy (Tsenkova, 2009), which, from a central element of state policy, has become a problem of individual inhabitants and a consequence of their credit worthiness. The second factor is related to the economic conditions of postsocialist societies and the presence of long-term residents (i.e. continuity of residence). It can probably be argued that the persistence of deprivation factors accompany, for example, the persistence of high social inequality rates. They accompanied the surge in property costs, the most dynamic being that in the period preceding the 2008 crisis (Racka et al., 2015). On the other hand, the weakness of supply perceptible in the dynamics of the real estate market (in conjunction with the state's assistance withdrawal) persistently leads to very high rates of buying and renting real estate regardless of their quality (Racka et al., 2015). The ineffectiveness of the transformation process of the capitalist city can also be probably analysed, where, after a proper lifting, the attributes of socialist modernism can retain their market attractiveness (which can be seen when living in blocks of flats is compared with living in other forms of residence). However, this explanation seems insufficient. The re-evaluation of block-shaped estates also partly concerns the changes in the collective identity, recognising and redefining the previously existent values that have since been deprecated to a certain extent due to the handicap of being 'low-born' (Springer, 2012a). It is also partly a pragmatic recognition that modernist infrastructure, in particular the housing infrastructure of LSBF, can be reconciled with the contemporary expectations and can be an important element of the social functioning of cities. Therefore, what seems most noticeable is the so-far-underestimated adaptability of socialist modernism to ongoing changes. Quite paradoxically, this old 'necessary evil' may be part of the vision of more sustainable neighbourly relations in the city, which stands in opposition to the threat sounded off almost 15 years ago by Kiril Stanilov on the basis of observations of the evolution of Central European cities after the 1989 transition (Stanilov, 2007a, b: 7).

One of the important secondary conclusions from the literature analysis (in the first part of the text) is the perception of two issues that have indirectly resounded in the conclusions of this article. Firstly, there are significant differences between the intensity of studies on the transformation of the socialist city in different parts of Central Europe. The southern part of the region is better described in this respect, and the conclusions are less optimistic than in the proposed study. Secondly, it is worthwhile to reflect on the different scale of

13 This can also be observed in the space of mass culture identifying real socialism with the specificity of urban neighbourhood relations in one block or on one staircase. In the centre of the estate, one can find equality planning concepts, uniformity and humorously described chronic dissatisfaction with the living conditions and the resulting cooperation. In the 1980s, this phenomenon was conveyed and depicted in numerous TV shows, such as in the series 'Alternatywy 4' directed by Stanisław Bareja (Mazierska, 2020). 
analysis of the LSBF phenomenon in relation to Central Europe, treating the experiences of the northern and southern parts of the region as different. The sources of these differences are not the same, but a change of perspective and perhaps a resumption of studies are worth considering.

\section{Declarations}

Conflict of interest The research process was organised and coordinated by the Social Research Centre of the Adam Mickiewicz University Foundation, which has experience in the ethical implementation of research involving human participants. Respondents were informed about their rights (by Polish and European legal standards), including providing informed consent for anonymised use of the social data produced. The authors declare no conflict of interest concerning both the research funder and the research provider.

Open Access This article is licensed under a Creative Commons Attribution 4.0 International License, which permits use, sharing, adaptation, distribution and reproduction in any medium or format, as long as you give appropriate credit to the original author(s) and the source, provide a link to the Creative Commons licence, and indicate if changes were made. The images or other third party material in this article are included in the article's Creative Commons licence, unless indicated otherwise in a credit line to the material. If material is not included in the article's Creative Commons licence and your intended use is not permitted by statutory regulation or exceeds the permitted use, you will need to obtain permission directly from the copyright holder. To view a copy of this licence, visit http://creativecommons.org/licenses/by/4.0/.

\section{References}

Baldwin Hess, D., Tammaru, T., \& van Ham, M. (2018). Lessons learned from a pan-European study of large housing estates: Origin, trajectories of change and future prospects. In D. Baldwin Hess, T. Tammaru, \& M. van Ham (Eds.), Housing estates in Europe poverty, ethnic segregation and policy challenges. (pp. 3-31). Springer.

Barczykowska, A. (2009). Wielkomiejskie zespoły mieszkaniowe jako środowisko życia. Studia Edukacyjne, 10, 129-145

Bierwiaczonek, K. (2018). Mikropolis w perspektywie badań nad tożsamością przestrzenną i sąsiedztwem. Miscellanea Anthropologica et Sociologica, 19(1), 269-286

Bujwicka, A.. (2011). Typy wielkomiejskiego sąsiedztwa wyobrażone a praktykowane stosunki sąsiedzkie mieszkańców Łodzi, Acta Universitatis Lodziensis,Folia Sociologica nr 36.

Bolt, G. (2018). Who is to blame for the decline of large housing estates? An exploration of socio-demographic and ethnic change. In D. Baldwin Hess, T. Tammaru, \& M. van Ham (Eds.), Housing estates in Europe poverty, ethnic segregation and policy challenges. (pp. 57-74). Springer.

Castells, M., \& Cardoso, G. (Eds.). (2005). The network society from knowledge to policy. Johns Hopkins Center for Transatlantic Relations.

Clark, A. (2009). From neighbourhood to network: A review of the significance of neighbourhood in studies of social relations. Geography Compass, 3(4), 1559-1578. https://doi.org/10.1111/j.1749-8198.2009. 00249.x

Coudroy de Lille, L. (2015). Housing cooperatives in Poland. The origins of a deadlock. Urban Research \& Practice, 8(1), 17-31. https://doi.org/10.1080/17535069.2015.1011424\#

Cymer, A. (2019). Building blocks: Poland's most popular homes, online material publisher on the site: Culture.pl. https://culture.pl/en/article/building-blocks-polands-most-popular-homes.

Diener, A. C., \& Hagen, J. (2013). From socialist to post-socialist cities: Narrating the nation through urban space. Nationalities Papers, 41(4), 487-514. https://doi.org/10.1080/00905992.2013.768217

Drozda, Ł. (2017). Urbanistyka socmodernistyczna na przykładzie polskich blokowisk z lat 70. i 80. $X X$ wieku, Studia Miejskie, 26, 113-124. https://doi.org/10.25167/sm2017.026.08

Enyedi, G. (1996). Urbanization under socialism. In G. Andrusz, M. Harloe, \& I. Szelenyi (Eds.), Cities after socialism.Blackwell Publishers Ltd.

Hałas, E. (2007). Culture and power: Possibilities and responsibilities for the world and society. Polish Sociological Review, 2(158), 146-158 
Hesse, M., \& Siedentop, S. (2018). Suburbanisation and suburbanisms-Making sense of continental European developments. Spatial Research and Planning, 76, 97-108. https://doi.org/10.1007/ s13147-018-0526-3

Hidalgo, C., \& Hernandez, B. (2001). Place attachment: Conceptual and empirical questions. Journal of Environmental Psychology, 21(3), 273-281. https://doi.org/10.1006/jevp.2001.0221

Hirt, S. (2013). Whatever happened to the (post)socialist city? Cities, 32(Supplement 1), S29-S38. https:// doi.org/10.1016/j.cities.2013.04.010

Jász, B. (2018). Hidden modernism: Architecture theory of the socialist realist gap. Periodica Polytechnica Architecture, 49(1), 1-6. https://doi.org/10.3311/PPar.12168

Kabisch, S., \& Grossmann, K. (2013). Challenges for large housing estates in light of population decline and ageing: Results of a long-term survey in East Germany. Habitat International, 39, 232-239. https://doi.org/10.1016/j.habitatint.2012.12.003

Kadushin, Ch. (1976). Networks and circles in the production of culture. American Behavioral Scientist, $19,769-784$

Kasarda, J. D., \& Janowitz, M. (1974). Community attachment in mass society. University of Chicago American Sociological Review, 39(June), 328-339. https://doi.org/10.2307/2094293

Kornai, J. (1980). Economics of shortage. I, II. Amsterdam: North Holland.

Kotus, J. (2006). Changes in the spatial structure of a large Polish city-The case of Poznań. Cities, 23(5), 364-381

Kotus. J. (2007), Natura wielkomiejskich sąsiedztw. Analiza subsąsiedzkich i sąsiedzkich terytorialnych podsystemów społecznych w Poznaniu, Uniwersytetim. Adama mickiewicza w Poznaniu Seria Beografia nr 77, Wydawnictwo Naukowe UAM, Poznań

Kovacs, Z., \& Herfert, G. (2012). Development pathways of large housing estates in post-socialist cities: An international comparison. Housing Studies iFirst article. https://doi.org/10.1080/02673037. 2012.651105

Kubeš, J. (2013). European post-socialist cities and their near hinterland in intra-urban geography literature. Bulletin of Geography. Socio-economic Series, 19, 19-43. https://doi.org/10.2478/ bog-2013-0002

Kryczka, P. (1981). Społeczność osiedla mieszkaniowego w wielkim mieście: ideologie i rzeczywistość, Warszawa: Państwowe Wydawnictwo Naukowe

L'Heureux, M.-A. (2015). The twentieth-century city: Socialist, capitalist, modern. Journal of Urban Cultural Studies, 2(3), 295-304. https://doi.org/10.1386/jucs.2.3.295_1

Łukasik, M. (2014). Renesans architektury modernizmu, jako fenomen społeczny. Politeja, 27, $245-262$. https://doi.org/10.12797/Politeja.11.2014.27.12

Lux, M., Kahrik, A., \& Sunega, P. (2012). Housing restitution and privatisation: Both catalysts and obstacles to the formation of private rental housing in the Czech Republic and Estonia. International Journal of Housing Policy, 12(2), 137-158. https://doi.org/10.1080/14616718.2012.681574

Majer, A. (2016). Miasto w osobistym wymiarze. Studia Miejskie, 21, 9-28

Marin, V., \& Chelcea, L. (2018). The many (still) functional housing estates of Bucharest, Romania: A viable housing provider in Europe's densest capital city. In D. Baldwin Hess, T. Tammaru, \& M. van Ham (Eds.), Housing estates in Europe poverty, ethnic segregation and policy challenges. (pp. 167-190). Springer.

Marriman, B. (2015). Three conceptions of spatial locality in Chicago school sociology (and their significance today). The American Sociologist, 46, 269-287. https://doi.org/10.1007/s12108-014-9239-4

Mazierska, E. (2020). The politics of space in Polish communist cinema. http://www.eki.ee $/ \mathrm{km} / \mathrm{place} /$ pdf/kp7_15_mazierska.pdf.

McKenzie, R. D. (1922). The Neighborhood: A study of Social Life in the city of Columbus. Ohio: The University of Chicago Press, Chicago Illinois.

Mumford, E. (2019). CIAM and its outcomes. Urban Planning, 4(3), 291-298. https://doi.org/10.17645/ up.v4i3.2383

Musil, J. (1993). Changing urban systems in post-communist societies in Central Europe: Analysis and prediction. Urban Studies, 30(6), 899-905

Musil, J. (2005). City development in Central and Eastern Europe before 1990: Historical context and socialist legacies. In FEl. Hamilton, K. D. Andrews, \& N. Pichler-Milanovi (Eds.), Transformation of cities in central and Eastern Europe: Towards globalization. (pp. 22-43). United Nations University Press.

Nikolić, S. (2019). Pastelosis—refurbishing of the PPR heritage. Urban Development Issues, 63, 51-64

Nowak, M., Pluciński, P., \& Siatkowski, A. (2019). Neighbourhood circles: The study of urban neighbourhood in contemporary Poland and its basic outcomes. Człowiek i Społeczeństwo, 48, 55-73. https://doi.org/10.14746/cis.2019.48.4 
Pescosolido, B. A., \& Rubin, B. A. (2000). The web of group affiliations revisited: Social life, postmodernism, and sociology. American Sociological Review, 65(1), 52-76

Pojani, D., \& Buka, M. (2015). From camaraderie to detachment: The effect of built environment transformations on neighbourhood relations in a post-socialist context. Cities, 49, 66-75. https://doi.org/ 10.1016/j.cities.2015.07.007

Rabaça, A. (2016). Le Corbusier, the city, and the modern utopia of dwelling. Journal of Architecture and Urbanism, 40(2), 110-120. https://doi.org/10.3846/20297955.2016.1183529

Rącka, I., Palicki, S., \& Kostev, I. (2015). State and determinants of real estate market development in Central and Eastern European countries on the example of Poland and Bulgaria. Real Estate Management and Valuation, 23(2), 74-87. https://doi.org/10.1515/remav-2015-0017

Radziszewska-Zielina, E., \& Gleń, M. (2014). Studies of the prefabricated housing construction market in Poland. SSP Journal of Civil Engineering, 9(2), 13-26. https://doi.org/10.2478/sspjce-2014-0012

Rowe, H. A. (2011). The rise and fall of modernist architecture. Inquiries Journal/Student Pulse, 3(04), 1/1

Smagacz-Poziemska, M. (2017). Badania nad społecznościami lokalnymi i sąsiedztwami w mieście-perspektywa socjologiczna. In G. Schneider-Skalska \& E. Kusińska (Eds.), Miejskie środowisko mieszkaniowe/Urban housing environment. (pp. 139-155). Politechnika Krakowska.

Smagacz-Poziemska, M., Bukowski, A., \& Kurnicki, K. (2018). Wspólnota parkingowania. Praktyki parkowania na osiedlach wielkomiejskich i ich strukturalne konsekwencje. Studia Socjologiczne, 1(228), 117-141. https://doi.org/10.24425/119089

Sosnowski, A., \& Walkowiak, J. (1983). Sąsiedztwo i jego odzwierciedlenie w świadomości mieszkańców wielkomiejskich osiedli. Studia Socjologiczne, 88(1), 223-244

Springer, F. (2012). Źle urodzone. Reportaże o architekturze PRL. Wydawnicwo Karakter.

Springer, F. (2012). Renesans polskiego modernizmu. Tygodnik Polityka. 7th of March. https://www.polit yka.pl/tygodnikpolityka/spoleczenstwo/1524955,1,renesans-polskiego-modernizmu.read, Accessed winter 2019.

Stanilov, K. (2007a). Taking stock of post-socialist urban development: A recapitulation. In K. Stanilow (Ed.), The post-socialist city urban form and space transformations in Central and Eastern Europe after socialism. (pp. 3-34). Springer.

Stanilov, K. (2007b). Housing trends in Central and Eastern European cities during and after the period of transition. In K. Stanilow (Ed.), The post-socialist city urban form and space transformations in Central and Eastern Europe after socialism. (pp. 173-190). Springer.

Staniszkis, J. (1992). The ontology of socialism. Clarendon Press, Oxford University Press.

Szafrańska, E. (2013). Large housing estates in post-socialist Poland as a housing policy challenge. European Spatial Research and Policy, 20(1), 119-129. https://doi.org/10.2478/esrp-2013-0006

Szafrańska, E. (2015). Ewolucja statusu społecznego i pozycji wielkich osiedli mieszkaniowych w strukturze rezydencjalnej miast postsocjalistycznych. wybrane przykłady. Acta Universitatis Łodziensis Folia Sociologica, 52, 45-76

Szwaja, K. (1970). Przemiany rodzin robotniczych pochodzenia wiejskiego $w$ wielkim mieście. Typescript reproduced, available in Archiwum Instytutu Socjologii UAM.

Thomas, W., \& Znaniecki, F. (1958). The Polish peasant in Europe and America, 1, 2. Dover Publication.

Tsenkova, S. (2009). Housing policy reforms in post-socialist Europe: Lost in transition. Physica-Verlag. https://doi.org/10.1007/978-3-7908-2115-4

Turowski, J. (1973). Socjologiczne aspekty społeczności osiedlowej. Studia Socjologiczne, 3, 215-238

Tuvikene, T (2017). Between Community and Private Ownership in Centrally Planned Residential Space: Governing Parking in Socialist Housing Estates,In Hess D., Tammaru T. (Eds). Housing Estates in the Baltic Countries The Legacy of Central Planning in Estonia, Latvia and Lithuania, SprongerOpen, https://doi.org/10.1007/978-3-030-23392-1

Wassenberg, F. (2018). Beyond an ugly appearance: Understanding the physical design and built environment of large housing estates. In D. Baldwin Hess, T. Tammaru, \& M. van Ham (Eds.), Housing estates in Europe poverty, ethnic segregation and policy challenges. (pp. 35-55). Springer.

Węcłowicz, G. (2016). Urban development in Poland, from the socialist city to the post-socialist and neoliberal city. The study has been realised within the confines of the research entitled "Social polarisation in the Hungarian and Eastern-Central European "new town" regions: Impacts of transition and globalisation' (K 106169). http://rcin.org.pl/Content/62816/WA51_81767_151633-r2016_Urban-Developmentin.pdf. Accessed winter 2019.

Woźniak, W. (2014). From underclass to Homo sovieticus: Human constraints towards modernization. Praktyka Teoretyczna, 3(13), 171-199. https://doi.org/10.14746/pt.2014.3.7

Ziółkowski, J. (1964). Osiedle jako system społeczny, Studia Socjologiczne, nr 2

Ziółkowski, J. (1965). Urbanizacja, miasto, osiedle. Studia socjologiczne. Warszawa: Państwowe Wydawnictwo Naukowe. 
Publisher's Note Springer Nature remains neutral with regard to jurisdictional claims in published maps and institutional affiliations.

\section{Authors and Affiliations}

\section{Marek Nowak $^{1} \mathbb{D} \cdot$ Andrzej Siatkowski $^{2}$}

$\triangle$ Marek Nowak

marek.nowak@amu.edu.pl

1 Sociology Faculty AMU, Adam Mickiewicz University, Szamarzewskiego 89c, 60-568 Poznań, Poland

2 AMU Foundation, Szamarzewskiego 89c, 60-568 Poznań, Poland 